UDC 631.1.027:388.432

JEL Classification: 032, M31, D22

DOI: 10.15587/2312-8372.2019.177294

\section{Spasskiy G., Tarasiuk A.}

\title{
RESEARCH OF MARKETING ACTIVITY OF AGRARIAN ENTERPRISES IN THE CONTEXT OF DEVELOPMENT OF INNOVATION PROCESSES
}

Об’єктом дослідження є процес управління інноваціями у маркетинговій діяльності аграрних підприємств, в тому числі фермерського господарства «Фенікс» (село Бадалово, Закарпатська область, Украйна). Одним з найбільш проблемних місць є низький рівень дієздатності підрозділів аграрного підприємства щодо маркетингової діяльності.

В ході дослідження використовувалися абстрактно-логічний, монографічний, розрахунково-конструктивний, економіко-статистичний та економіко-математичний методи, а також методи аналізу та синтезу. Отримані результати дослідження стосовно функціонування маркетингу в аграрних підприємствах показали, що активізація розвитку маркетингової діяльності та перехід до більш прогресивних концепцій напряму залежить від ефективності реалізаиї маркетингових стратегій. Також показано, шо вирішення проблеми підвищення економічної діяльності аграрних підприємств на ринку передбачається за допомогою організачійно-економічних змін, спрямованих на зниження виробничих та забезпечення економічних результатів збутової діяльності. Встановлено, що в умовах коли на ринку сільськогосподарської продукиї існує високий рівень конкуренцї, саме маркетингова діяльність є визначальним чинником, що забезпечує наявність конкурентних переваг. Визначено, що головними заходами для інновачійного аграрного підприємства є:

- проведення маркетингових досліджень;

- вживання маркетингових напрямків для просування інновацій;

- будування системи взаємовідносин з іншими учасниками інноваційного процесу.

Враховуючи постійно зростаючий інтерес до інновацій, як ключового чинника успіху в зміцненні позицій підприємства на ринку, автори стверджують, що інновачійна та маркетингова діяльність аграрних підприємств є базовими напрямками іх успішного розвитку. А також пропонують розробити методичні підходи до формування методів управління на засадах маркетингу та шляхи запровадження і удосконалення системи маркетингового управління в аграрних підприємствах.

Завдяки проведеним у фермерському господарстві дослідженням обгрунтовано пропозииї щодо впровадження, розвитку і оптимізацї системи нульового обробітку грунту No-till y фермерському господарстві «енікс».

Ключові слова: управління інноваційними процесами, маркетинг інновацій, аграрні підприємства, технологія No-till, чинники впливу на інноващійну діяльність.

Received date: 05.06.2019

Accepted date: 18.06 .2019

Published date: 30.08 .2019
Copyright (c) 2019, Spasskiy G., Tarasiuk A. This is an open access article under the CC BY license (http://creativecommons.org/licenses/by/4.0)

\section{Introduction}

The transformation of the country's economy has led agrarian enterprises to seek new approaches, ways, methods and mechanisms to achieve competitive advantages in a dynamic market. This situation requires the management of the agricultural enterprise to build a strategy for its development on the basis of certain innovative management methods.

The experience of foreign agricultural enterprises that are leaders in the industry, Ukraine's transition to an innovative development path, as well as existing trends in increasing the number of innovative processes indicate that in modern conditions the main tools of entrepreneurship are innovative processes. It is these processes that can ensure the further development of Ukrainian enterprises of agricultural entrepreneurship, allow them to compete in the domestic and world markets, and it is precisely on their implementation that it is necessary to focus attention.

Now the main criteria for the effective development of the country, its regions, types of economic activity, individual business entities in agriculture are the quality and speed of implementation of new information technology systems and management methods. Given the new realities of economic life and international economic relations, there is a need for new approaches to innovation policy, building an innovative type of economy. In this case, a greater susceptibility of objects and subjects of innovation to the elements of the innovation process 
is characteristic, where the achievements of science and technology are interconnected with the development of agricultural production of high technology products and the developed infrastructure for supporting innovation.

The formation of innovation marketing as a scientific discipline in the world took place only in recent decades and in Ukraine much later. It has been established that while in developed countries innovation marketing is an important element of innovation and a component of success in any entrepreneurial activity, then at Ukrainian agricultural enterprises too little attention is paid to it. At the same time, a dynamic environment and fierce competition encourages the introduction of effective changes in agricultural enterprises in its economic activities, which determines the relevance of research.

So, one of the most important factors in increasing innovation activity in enterprises - use of marketing innovation, which is an integral part of the process of developing, introducing into production and promoting a new product.

\section{The object of research and its technological audit}

The object of research is the process of innovation management in the marketing activities of agricultural enterprises, including the Phoenix farm (Badalovo village, Zakarpattia region, Ukraine).

The issues of innovative development of Ukrainian agricultural enterprises were solved at a much slower pace than in industry, and the development of methodological and basic issues of the construction and functioning of the innovation process in the agricultural sector has not yet found an appropriate level of development and adaptation. Given the ever-growing interest in innovation, as a key success factor in strengthening the company's position in the market, it can be argued that the innovative activity of agricultural enterprises is the basic direction for the development of marketing activities. The study of these two components of activity creates the prerequisites for the formation of a new concept of marketing innovation, which integrates the methods and approaches of these types of activities into a single methodology. It is also intended to improve the management of enterprise innovative resources in order to conquer the market.

One of the most problematic places is the low level of legal capacity of the departments of the agricultural enterprise for marketing activities. There are also a number of problems with the current state of the innovation process management system in the marketing activities of agricultural enterprises.

The problem is the uncertainty in the activities of the marketing department in an agricultural enterprise. One gets the impression that it is not in agricultural enterprises and there is no one to promote the product to the consumer without intermediaries in the market.

\section{The aim and objectives of research}

The aim of research is the justification and applied processing of innovative processes in the marketing activities of agricultural enterprises.

To achieve this aim, the following tasks were solved:

1. To develop a system for managing innovative processes of an agricultural enterprise.
2. To propose an innovative project to introduce elements of No-Till resource-saving technology in the farm «Phoenix».

3. To determine the factors influencing innovation in the marketing activities of an agricultural enterprise.

\section{Research of existing solutions of the problem}

In modern conditions, the problem of marketing innovation in the scientific literature pays a lot of attention. Thus, issues of marketing innovation were investigated in the works of leading marketing theorists [1, 2], who single out marketing as one of the determining factors for a successful innovative product on the market. However, in the works of these researchers there is no solution to the problem of researching the functioning of the market of marketing innovations in agricultural enterprises of Ukraine.

Given the ever-growing interest in innovation, as a key success factor in strengthening the company's position in the market, it can be argued that the innovative and marketing activities of agricultural enterprises are the basic directions for their successful development. In this regard, the author of [3] claims that it is necessary to realize the importance of introducing zero No-till technology in Ukraine. Since the state should take this matter into its own hands and stimulate and support the most active participants in the introduction of new technology. The author of [4] emphasizes that the future lies in zero tillage and that subsidies are required for the acquisition of continuous herbicides and the latest technology for this technology. However, it's impossible to say that No-till technology will save from all troubles.

From another point of view, representatives of science act as researchers and theorists of marketing innovations, consultants as practitioners who are interested in using the latest effective marketing tools in agricultural enterprises [5]. Market participants replenish information through cooperation, publications, participation in conferences, seminars, exhibitions, round tables, etc. [6]. But in modern conditions, theorists do not pay due attention to the implementation of their developments in agricultural enterprises and do not take appropriate part in conferences, seminars, and exhibitions.

In order for an agricultural enterprise to be successful in the implementation of its innovation and marketing innovation was effective, a prerequisite is the presence of a certain potential for innovative development [7]. It is noted that the peculiarities of the implementation of marketing and innovation is that with the introduction of innovations in agricultural production, types of products, as a rule, do not change, but only acquire improvement [8]. Over time, it is necessary to change the range of production of goods and food. And also to reduce the production costs of agricultural enterprises, optimize personnel and produce high-quality products.

Further studies are aimed at identifying the main factors that will determine the degree of participation of an agricultural enterprise in the innovation process $[9,10]$.

Let's believe that the main factors that impede the implementation of innovations in agricultural enterprises are:

- complete lack of own funds;

- high cost of innovation;

- lack of financial support from the state;

- complete lack of information on new technologies;

- low innovative potential of enterprises. 
Therefore, research on the management of innovative processes in the marketing activities of agricultural enterprises remains a promising area for scientific research in the field of theory and practice.

\section{Methods of research}

During the research, the following methods are used: - abstract-logical - in the formation of the logicalstructural diagram of the study, the definition of classification criteria, the formulation of scientific provisions and the definition of categories and concepts;

- monographic - in the study of the results of activities of agricultural enterprises and their associations;

- design-constructive - in determining indicators of the effectiveness of the use of marketing and marketing strategies of agricultural enterprises;

- economic-statistical and economic-mathematical methods - when performing calculations and determining performance indicators and researching specific structures of target markets;

- methods of analysis and synthesis - in formalizing and assessing the impact of factors, determining typological and classification characteristics of marketing and marketing tools for strategic management of agricultural enterprises

\section{Research results}

Under current conditions, only those agricultural enterprises can survive and function effectively, whose management is looking for ways to adapt to the constantly changing environmental conditions, and improves management and organization of economic activity [11].

It is proved that the management of innovative processes in the activities of agricultural enterprises contains a combination of economic, organizational and motivational actions aimed at:

- ensuring effective planning, development and use

of the results of these processes;

- increasing innovative culture;

- formation of economic thinking in intellectual labor.
Innovative activity is risky. To reduce and manage this risk, an innovation process management system should be created in an agricultural enterprise with an important component - innovation marketing. The main features of the enterprise innovative development management system are:

- focus on internal production relations;

- company must make full use of existing and promising market opportunities for innovative development in order to achieve success in competition and maximize revenues.

The effectiveness of this system will depend on the smooth operation of all its subsystems (Fig. 1).

Research and analysis of market needs and environmental influences systematizes the information collected in order to determine and implement the innovative strategy of business entities. At the same time, they analyze information about the market, the structure and dynamics of demand, the desire of customers, the activities of competitors, the possibility of similar products from competitors. It should be noted that marketing research is important at every stage of the innovation process: from the accumulation of knowledge to the commercialization of innovation.

The interaction of organizations of the innovation market (market entities) and its infrastructure ensures the cooperation of agricultural enterprises in:

- research, scientific and technical organizations;

- centers of certification, metrology, standardization, examination;

- consulting and engineering companies;

- information centers and other infrastructure organizations.

The objectives of the commercialization of innovations are the strategic promotion of the development market, ensuring the conditions for obtaining the maximum benefit from the commercialization of innovations, ensuring the legal protection of intellectual property and rights to their property.

For effective management of the innovation marketing subsystem in an agricultural enterprise, marketing itself must be innovative, that is, using the latest effective technologies and tools. Some external and internal factors should stimulate the innovative activity of the agricultural enterprise in marketing activities, while others restrain this process (Fig. 2).

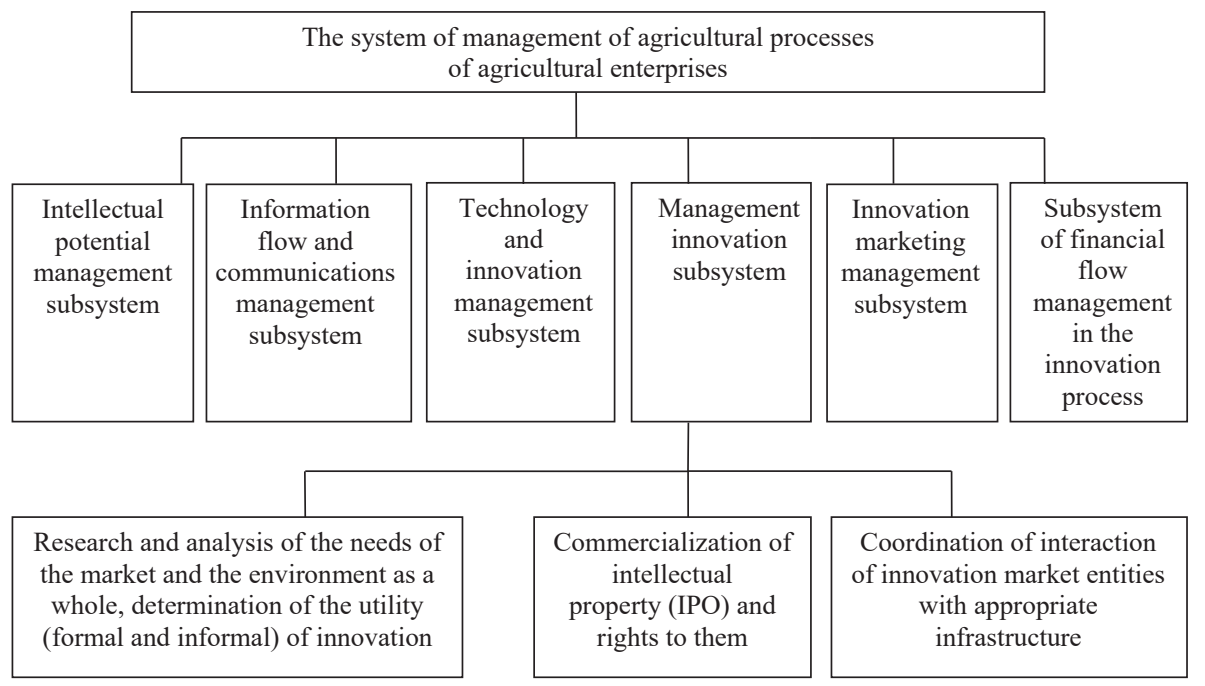

Fig. 1. The system of management of innovative processes of an agricultural enterprise (developed by the authors on the basis of studies of medium-sized agricultural enterprises of the Zakarpattia region, Ukraine and work [12]) 


\begin{tabular}{|c|c|c|}
\hline $\begin{array}{l}\text { EXTERNAL } \\
\text { - changes and innovations in } \\
\text { the science and practice of } \\
\text { marketing activities; } \\
\text { - increased competition } \\
\text { In the market; } \\
\text { - growth of complexity, } \\
\text { variability, uncertainty of the } \\
\text { external environment; } \\
\text { - introduction of marketing } \\
\text { innovations by competitors; } \\
\text { - level of development of the } \\
\text { market of organizational and } \\
\text { managerial innovations }\end{array}$ & $\begin{array}{l}\text { Factors } \\
\text { affecting } \\
\text { innovation in } \\
\text { the marketing } \\
\text { activities of an } \\
\text { agricultural } \\
\text { enterprise }\end{array}$ & $\begin{array}{l}\text { INTERNAL } \\
\text { - high qualification of } \\
\text { marketing specialists; } \\
\text { - innovative activities of the } \\
\text { head and marketing specialist } \\
\text { - stimulation and motivation } \\
\text { innovative activity in an } \\
\text { agricultural enterprise; } \\
\text { - level of competitiveness of } \\
\text { goods and enterprises; } \\
\text { - slow response to market } \\
\text { changes; } \\
\text { - development and launch of } \\
\text { new product on the market }\end{array}$ \\
\hline \multicolumn{3}{|c|}{ Factors hindering innovation in the marketing activities of an agricultural enterprise } \\
\hline $\begin{array}{l}\text { - conservative views o } \\
\text { - lack of organizationa } \\
\text { - lack of established in } \\
\text { - lack of staff motivati } \\
\text { - resistance of the staff } \\
\text { - low qualification of }\end{array}$ & $\begin{array}{l}\text { and specialists } \\
\text { imed at innovativ } \\
\text { external commur } \\
\text { icultural enterpri } \\
\text { of an agricultura }\end{array}$ & $\begin{array}{l}\text { cultural enterprise; } \\
\text { pment; } \\
\text { inks; } \\
\text { se }\end{array}$ \\
\hline
\end{tabular}

Fig. 2. Factors of influence on innovation in the marketing activities of an agricultural enterprise (developed by the authors on the basis of [12])

In modern conditions, by marketing innovation let's mean the result of the transformation of ideas in the field of marketing activity into a new or improved economic solution, which is in demand on the market by the consumer. Marketing innovation - an innovation in marketing activities, first introduced in the organization, makes changes in the way the marketing activities of an agricultural enterprise operate and is aimed at its development, obtaining competitive advantages, achieving a certain economic effect.

The basis of the research of innovative development was the farm - then Phoenix farm, Badalovo village, Berehove district, Zakarpattia region, Ukraine. Phoenix farm is mainly engaged in the production of crop products, namely it specializes in growing crops (the largest areas are allocated for winter crops for grain). However, the level of efficiency of such production varies significantly from year to year. Managed for the enterprise factor, which forms the profitability of production, is the cost of production. A farm can influence it by changing technology, sources of resources. To increase profitability, resourcesaving technologies should be used that not only reduce costs, but also preserve the environment.

The studied Phoenix farm aims to improve economic and financial results. To this end, let's propose to implement an innovative project for introducing elements of resource-saving No-till technology. No-till technology is the introduction of resource-saving crop production, the purpose of which is to achieve acceptable profitability along with full reproduction of production, while preserving the environment.

Key benefits of No-till technology:

1) increasing labor productivity by $3-4$ times and reducing the cost of growing crops by $2-3$ times;

2) reduction of expenses for the purchase of fuel, fertilizers, plant protection products, and other material costs;

3) sowing and harvesting is carried out in the best agrotechnical terms, reduced by $1.5-2$ times;

4) increasing the yield of crops;
5) minimizing erosion processes and increasing the content of organic matter and humus in the soil;

6) conservation of soil moisture from losses due to physical evaporation and other advantages [3].

But the disadvantages in No-till can be significant. In the presence of crop residues on the surface, the temperature of the soil in spring is lower by $3 \ldots 5{ }^{\circ} \mathrm{C}$, due to which the stages of organogenesis of field crops are shifted to a later date. This leads to a delay (with corresponding consequences) in the sowing of spring crops.

If the soil is poorly drained, there is a danger of overmoistening the arable layer of the soil, and, consequently, a decrease in its biological activity. This must be borne in mind when deciding where to introduce No-till technology. According to the saturation of the seed layer of the soil of plant residues, it may be necessary to increase seeding rates by $15-25 \%$. It becomes more difficult to control the weeds of crops, the cost of herbicides can grow by 15-100\%, depending on the crop and type of crop rotation.

According to No-till technology, the effect of soil herbicides is deteriorating, since some of the preparations are contained in crop residues, intensely detoxify in the biologically active surface layer. The presence of plant residues creates favorable conditions for the emergence and preservation of sources of infections, pests, favorable conditions arise for the survival of pests in the winter, and the fight against mouse rodents is complicated.

In the presence of a large number of crop residues, the efficiency of nitrogen feeding by the scattering method decreases, up to a third of urea is possible. As for environmentally friendly products, in Ukraine, as well as around the world, it is impossible to get high yields without the use of mineral fertilizers and pesticides. So, in Ukraine, the best land in the world, but even it will not yield a high crop if it is not fertilized and fought against diseases and pests. For example, Fusarium mold on wheat is more toxic than chemicals used against it [3, 4]. No-till technology requires an extremely high qualification of agronomic and technical personnel. 
To switch to No-till, first of all, it is necessary to purchase imported equipment (tractors, seeders, sprayers, fertilizer spreaders, tillage complexes and combine harvesters). Why imported? Because a complex of mechanisms for No-till technology is not produced in Ukraine, and it must be imported from abroad, in the face of a significant devaluation of the hryvnia and the financial crisis, it becomes problematic. The disadvantage of No-till technology is the high price of the main technical tool direct seeders. Here the price can be tens and hundreds of thousands of dollars [4].

The investment policy of the enterprise provides that the return on investment should not exceed 5 years, therefore, calculations should be carried out during this period. As an innovative project, let's choose the application of technology in the production of winter wheat grain (Table 1).

Table 1 confirms the data of the flow chart, with No-till technology, the enterprise spends less on fuel costs, which is beneficial for this agricultural enterprise. The seed variety is selected high-quality «Ortegus», «Auriyka» or «Mulan», mineral fertilizers are applied traditional, Ukrainian and foreign production. Gradual transition to the acquisition of seeds and mineral fertilizers of Ukrainian production.

Depreciation charges are formed taking into account the cost of a new sowing complex. In order to calculate how effective and profitable No-till technology is, it is necessary to calculate financial indicators.
The financial indicators in the work were calculated by the generally accepted arithmetic method. Sales revenue was determined depending on the price prevailing in the regional market in the second (20-30\%) and 3rd (50-60\%) classes of winter wheat. The gradual increase in the price and yield of winter wheat was taken into account. The calculation results are shown in Table 2 .

Having analyzed the Table 2, it is possible to conclude that the No-till technology for use in the Phoenix farm is quite profitable, since even after a large amount of expenses the farm received a net profit.

Innovations in marketing can be classified as intended for a specific agricultural enterprise and for presentation on the market (as services). The transfer of the first type of innovation occurs:

- by publishing the works of scientists and practitioners;

- through participation in conferences, seminars, round tables;

- during training, internship and retraining of personnel;

- in the integration of enterprises.

At the same time, creative works (articles, books, reports, etc.) are copyrighted. The commercial provision of services for the introduction of innovations in marketing, as well as services for marketing innovations, can occur through individual services of consulting firms, autosourcing companies, training seminars and lectures.

Table 1

The cost of growing winter wheat using No-till technology

\begin{tabular}{|l|c|c|c|c|c|}
\hline \multirow{2}{*}{ Indicator } & \multicolumn{5}{c|}{ Year } \\
\cline { 2 - 6 } & 2021 & 2022 & 2023 & 2024 & 2025 \\
\hline Area, ha & 600 & 550 & 550 & 500 & 500 \\
\hline The cost of seeds, UAH/USD & $2063500 / 79365$ & $1985310 / 76358$ & $19744550 / 75940$ & $1897900 / 72996$ & $1879500 / 72289$ \\
\hline Fertilizers, UAH/USD & $632100 / 24312$ & $628900 / 24188$ & $626700 / 24103$ & $610230 / 23470$ & $606950 / 23344$ \\
\hline Costs of plant protection products, UAH/USD & $1013230 / 38970$ & $953300 / 36665$ & $948110 / 36466$ & $939500 / 36135$ & $918200 / 35315$ \\
\hline Payment expenses & $935100 / 35965$ & $955400 / 36746$ & $956700 / 36796$ & $958400 / 36862$ & $959520 / 36904$ \\
\hline labor UAH/USD & $550300 / 21165$ & $514500 / 19788$ & $506550 / 19483$ & $484510 / 18636$ & $474430 / 18247$ \\
\hline Fuel costs, UAH/USD & $451050 / 17348$ & $430550 / 16561$ & $409550 / 15752$ & $402750 / 15490$ & $387670 / 14911$ \\
\hline Dther expenses, UAH/USD & $450500 / 17327$ & $449500 / 17289$ & $448500 / 17251$ & $431200 / 16584$ & $430510 / 16558$ \\
\hline Depreciation, UAH/USD & $6095780 / 234452$ & $5917460 / 227595$ & $5870560 / 225791$ & $5724490 / 220173$ & $5656780 / 217568$ \\
\hline
\end{tabular}

Note: calculated according to the ratio of the currency (1 USD - 26 UAH). Data taken from the technological map for $2021-2025$ on the cultivation of winter wheat, which was developed at the «Phoenix» farm. Whenever possible, all factors that affect the process were taken into account.

Table 2

Financial results of the implementation of No-till technology, UAH/USD

\begin{tabular}{|l|c|c|c|c|c|}
\hline \multirow{2}{*}{ Indicators } & \multicolumn{4}{c|}{ Year } \\
\cline { 2 - 6 } & 2021 & 2022 & 2023 & 2024 & 2025 \\
\hline Revenue from sales of commercial products & $18150200 / 698084$ & $18534400 / 712861$ & $18744500 / 720942$ & $19078900 / 733803$ & $204567770 / 786799$ \\
\hline Operating expenses (including logistics costs) & $8109500 / 311903$ & $8256780 / 317586$ & $8357860 / 321456$ & $8497500 / 326827$ & $8564500 / 329403$ \\
\hline Depreciation (amortization amount) & $450500 / 17327$ & $449500 / 17228$ & $448500 / 17250$ & $431200 / 16584$ & $430510 / 16558$ \\
\hline Profit & $9590200 / 368854$ & $9828120 / 378005$ & $9938140 / 382236$ & $11050200 / 425008$ & $11461760 / 440837$ \\
\hline Tax & $175500 / 6750$ & $176400 / 6785$ & $176550 / 6790$ & $176150 / 6775$ & $176500 / 6788$ \\
\hline Net profit & $9414700 / 362104$ & $9651720 / 371220$ & $9761590 / 375446$ & $9874050 / 379771$ & $11285260 / 434048$ \\
\hline Net cash receipts & $9865200 / 379431$ & $10101220 / 388508$ & $10210090 / 392696$ & $10305250 / 396356$ & $11715770 / 450606$ \\
\hline
\end{tabular}

Note: calculated according to the ratio of the currency (1 USD - 26 UAH) 
In the market of marketing innovations, there is an interaction of agricultural enterprises, scientific institutions and consulting companies (independent consultants) (Fig. 3).

For the functioning and development of an innovative economy based on knowledge and information, it is necessary to create appropriate conditions, in particular, the formation of a modern innovation market, including their various types, primarily marketing. Sources of competitive advantage are not only technical and technological innovations, but also organizational and managerial innovations, one of which is marketing. Moreover, in a crisis and insufficient financial resources for the implementation of the former, many enterprises can increase their competitiveness due to the latter, which do not require a lot of time and money.

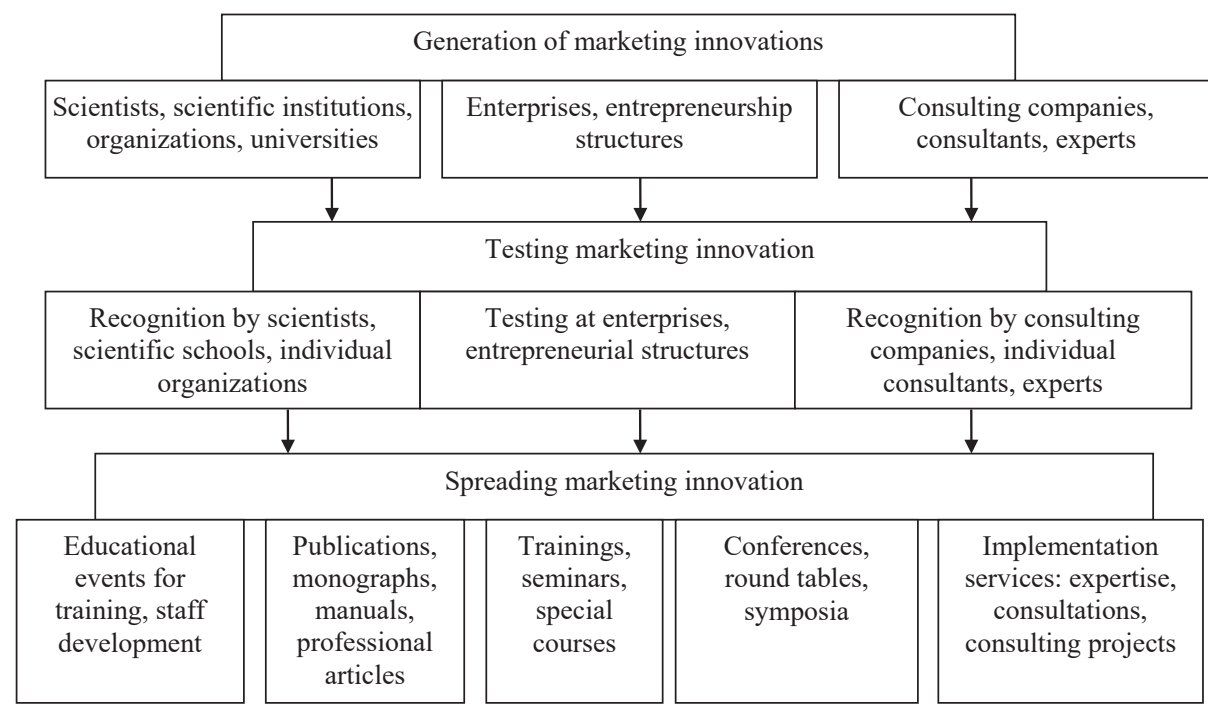

Fig. 3. The interaction of market innovations of marketing innovations with the stages of the innovation process (developed by the authors on the basis of [13])

Studies confirm that agricultural enterprises, which are mainly engaged in the production of crop products, are trying to develop using various innovative technologies, such as No-till, Mini-till, the use of a sprayer, the mechanical collection of fruits and vegetables, and the introduction of new technology in agricultural production. Among the agricultural enterprises that are engaged in the production of mainly livestock products, the majority introduce the latest production technologies for the production of milk, livestock feeding. The main goals of introducing innovations in agricultural enterprises are updating obsolete resources or processes, entering new markets or increasing market share (niches in the regional market). This will lead to a reduction in labor costs, materials and energy per unit of output.

At the same time, agricultural enterprises are much less interested in reducing the negative impact on the environment and expanding the range of food products. The main obstacles to the development of innovation in Ukrainian agricultural enterprises are: for crop enterprises - price factors, and for livestock - price and information.

So, in plant breeding, the introduction of innovations is hindered mainly (in decreasing order of importance of factors) due to the lack of own funds of the enterprise and financing from other sources, as well as too high costs of innovation. Along with this, innovative activity in livestock farming is constrained by the too high costs of innovation and the lack of information on markets for innovative products and financing from attracted sources [13].

It has been established that innovation policy requires the introduction of innovations in the activities of agricultural enterprises in order to ensure customer satisfaction and optimal production load. It regulates a complex system of scientific, technical, marketing, managerial, industrial and economic activities [14].

The achieved level of agricultural production efficiency for crops is insufficient to ensure expanded reproduction and requires further development with the attraction of additional investments and innovative solutions [11].

One of the main conditions for the stability of an enterprise in the market is the coordination of actions that form a marketing activity with the organization of production. Marketing should influence production depending on the state of demand and the availability of competitive products [8].

It is clear that now there are many theoretical and applied problems that hinder the effective and high-quality development of agricultural enterprises in this case, Phoenix farm. However, this approach will allow to combine the effectiveness of innovative economic activities of agricultural enterprises, and therefore, serve to achieve the strategic goals of the enterprise under study.

\section{SWOT analysis of research results}

Strengths. The analysis will contribute to the search for reduced costs in the farm, as well as increased yield of winter wheat.

Weaknesses. The implementation of proposals will require expensive foreign technology when implemented in practice.

Opportunities. The interaction of innovation market entities, that is, the cooperation of agricultural enterprises with research, scientific and technical organizations, certification, standardization centers, information centers gives:

- opportunities for strategic promotion to the development market;

- providing conditions for maximizing the benefits of commercialization of innovations;

- ensuring legal protection of intellectual property.

Threats. Threats to implement the results of the study are:

- changing laws on the economic sphere of Ukrainian agricultural production;

- when introducing No-till technology, the soil is poorly drained, there is a danger of overmoistening the arable layer of the soil, and, consequently, a decrease in its biological activity; 
- in the presence of nutrient residues, the efficiency of nitrogen preparation by the scattering method decreases, up to a third of urea is lost.

\section{Conclusions}

1. A system for managing innovative processes has been developed that will reduce the risks in the innovation activities of agricultural enterprises. The main features of the enterprise innovative development management system are:

- focus on internal production relations;

- company must make full use of existing and promising market opportunities for innovative development in order to achieve success in competition and maximize revenues.

The effectiveness of the developed system will depend on the functioning of the proposed subsystems. The set of elements of the managerial process of innovative development of an agricultural enterprise is proposed on the basis of studies of medium-sized agricultural enterprises of the Zakarpattia region.

2. To improve economic and financial results, the implementation of an innovative project on the management of elements of resource-saving technology No-till is proposed. This technology guarantees full reproduction while preserving the environment. No-till technology or a zero tillage system provides for the rejection of plowing the land, the use of crops of cover crops and the competent use of crop rotation. All work is carried out by a special seeder, which cuts off nutrient residues, distributes them on the ground, makes a furrow of the required depth in it, plants seeds and wraps it. No-till is based on soil protection: sowing is carried out in nutrient residues with minimal disturbance in their structure and without mechanical impact on the soil. Along with this, the new technology allows to increase labor productivity by $3-4$ times, reduce fuel costs by $2-3$ times.

3 . In the course of research, the factors of influence on innovative activity in the marketing activities of an agricultural enterprise are determined. Factors such as: negatively affect innovation in the marketing activities of an agricultural enterprise:

- low level of cooperation in the scientific and industrial spheres;

- limited material and financial resources;

- low technical level of experimental and production bases and level of perception.

Activate the same innovative activities at the enterprise such factors as:

- type of ownership;

- territorial factor and innovation infrastructure;
- information support;

- staff training and product competitiveness.

A significant part of the factors should stimulate the innovative activity of the agricultural enterprise in marketing activities.

\section{References}

1. Kotler, P. T., Armstrong, G. (2017). Principles of Marketing. Pearson, 736

2. Cravens, D. W. (1997). Strategic Marketing. Irwin, 670

3. Martyniuk, A. Yu. (2013). Innovatsiini tekhnolohii NO-TILL v silskomu hospodarstvi yak osnova pidvyshchennia efektyvnosti ahrarnoho vyrobnytstva. Zbirnyk naukovykh prats Umanskoho ahrarnoho instytutu, 83, 219-226.

4. Perehuda, V. V. (2008). Tekhnolohiia No-till: arhumenty «za». Propozytsiia, 3, 35-39.

5. Malik, M. Y. (2005). Metodychni pidkhody do orhanizatsii marketynhu innovatsii naukovoho rynku ahropromyslovoho vyrobnytstva. Ekonomika APK, 8, 22-26.

6. Zaitsev, Yu. O. (2016). Mekhanizm stratehichnoho upravlinnia marketynhovym zbutom tovarnoi produktsii ahrarnykh pidpryiemstv. Visnyk Kharkivskoho natsionalnoho ahrarnoho universytetu, 2, 215-219.

7. Evans, J. R., Berman, B. (1996). Marketing. Subsequent Edition. Pearson College Div, 679.

8. Borg, E. A. (2009). The marketing of innovations in hightechnology companies: a network approach. European Journal of Marketing, 43 (3/4), 364-370. doi: http://doi.org/ 10.1108/03090560910935479

9. Maciariello, J. A. (2018). Drucker, Peter: The Drucker Strategic Management System. The Palgrave Encyclopedia of Strategic Management, 431-440. doi: http://doi.org/10.1057/978-1-13700772-8_629

10. Vega-Jurado, J., Juliao-Esparragoza, D., Paternina-Arboleda, C. D., Velez, M. C. (2015). Integrating Technology, Management and Marketing Innovation through Open Innovation Models. Journal of Technology Management E Innovation, 10 (4), 85-90. doi: http://doi.org/10.4067/s0718-27242015000400009

11. Spaskyi, H. V. (2017). Innovatsii v rozvytku ahrarnykh pidpryiemstv Zakarpatskoi oblasti. Visnyk ahrarnoi nauky, 10, 67-73.

12. Zaburanna, L. V., Zaburannyi, S. V. (2015). Rozvytok innovatsiinykh protsesiv v ahrarnii sferi. Ahrosvit, 18, 3-9.

13. Yankovska, O. I. (2010). Stan upravlinnia innovatsiinymy protsesamy $\mathrm{v}$ pryvatnykh silskohospodarskykh pidpryiemstvakh Zhytomyrskoi oblasti. Visnyk Zhytomyrskoho natsionalnoho ahroekolohichnoho universytetu. Seriia: Ekonomichni nauky, 2 (2), 173-180.

14. Crow, A. (2000). Marketing of innovation. Available at: http:// www.urenio.org/tools/en/marketing_of_innovation.pdf

Spasskiy Gabriel, Doctor of Economic Sciences, Leading Researcher, Department of Entrepreneurship, Cooperation and Agro-Industrial Integration, National Scientific Centre «Institute of Agrarian Economics», Kyiv, Ukraine, e-mail: gspasskiy@ukr.net, ORCID: http:// orcid.org/0000-0002-3549-0711

Tarasiuk Andrey, Postgraduate Student, Department of Entrepreneurship, Cooperation and Agro-Industrial Integration, National Scientific Centre «Institute of Agrarian Economics», Kyiv, Ukraine, ORCID: http://orcid.org/0000-0003-3097-7448 